УДК 37.015.311:1

DOI:

Микола Вовчанський, аспірант кафедри технологічної та професійної освіти Дрогобииького державного педагогічного університету імені Івана Франка

\title{
ФІЛОСОФСЬКІ ЗАСАДИ ТА СТРУКТУРА ЕКОЛОГІЧНОЇ КУЛЬТУРИ ОСОБИСТОСТІ
}

У статті на основі аналізу існуючих проблем у галузі екологічної освіти та виховання здійснено спробу визначити та схарактеризувати сутність та структурні компоненти екологічної культури особистості.

3'ясовано, шо екологічна культура особистості - ие сочіальна й індивідуальна якість людини, яка, по-перше, відображає характер ї̈ ставлення до соичіоприродного середовища; по-друге, виявляється в ціннісних орієнтаціях, котрі мотивують екологічну діяльність; по-третє, реалізується в усіх видах пізнання, перетворення та збереження соиіоприродного довкілля $i$ здоров'я людини; по-четверте, зумовлена соціальним механізмом ї̈ формування та розвитку. Вона формується в результаті взаємодіі об'єктивних умов (система сочіальних інститутів, відносин $і$ зв'язків, які ставлять певні вимоги до особистості) та суб 'єктивних чинників (сочіально зумовлені спонукальні сили особистості).

Ключові слова: екологія; екологічна криза; екологічна культура; особистість; якість.

Jim. 8.

Mukola Vovchanskiy, Postgraduate Student of the Technological and Vocational Education Department Drohobych Ivan Franko State Pedagogical University

\section{PHILOSOPHICAL BASES AND THE STRUCTURE OF ENVIRONMENTAL CULTURE OF PERSONALITY}

The article attempts to identify and characterize the essence and structural components of the ecological culture of the individual on the basis of analysis of existing problems in the field of environmental education and upbringing.

There is certain ambiguity regarding the interpretation of the essence and structure of ecological culture in the scientific literature, where the ecological culture of the individual is usually associated with the following aspects: the responsible attitude of person towards nature; the amount of ecological awareness and beliefs, acquiring skills and experience of solving the environmental problems; ecologically competent activity in the natural environment; the need of communication with nature, care of its preservation; care of own health; civic responsibility for the state of the socio-natural environment.

Furthermore, nowadays the ecological issues are comprehensively covered by the culture studies in two directions: as a culture of society and as a culture of personality. From the point of view of the former, ecological culture is treated as a social phenomenon and within the framework of the latter approach the ecological culture is considered to be as an integrative personal quality of the individual, which characterizes the activity and behavior in the socio-natural environment.

As the study shows the ecological culture of the person is a social and individual quality of the person, which, firstly, reflects the nature of relation to the socio-natural environment; and secondly, it is revealed in value orientations that motivate the environmental activity; thirdly, it is realized in all kinds of knowledge, transformation and preservation of the socio-natural environment and human health; fourth, it is conditioned by the social mechanism of its formation and development.

It is formed as a result of the interaction of objective conditions (the system of social institutions, relations and relationships, which put forward certain requirements before the individual) and subjective factors (sociallypredetermined incentive forces of the individual). The analysis of scientific-pedagogical literature makes it possible to distinguish the following main indicators of the ecological culture of the individual: the ecological worldview, value reference, cognitive, moral-legal, sensory-volitional and actionable components.

Keywords: ecology; ecological crisis; ecological culture; personality; a quality.

$\Pi$ остановка проблеми. Історія розвитку людського суспільства безпосередньо пов'язана з природою,

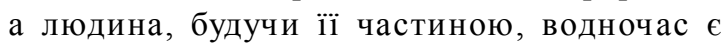
частиною тисячоліттями нею створюваної культури. 3 іншого боку, вся історія людства - це історія поглиблення суперечностей між загальним екологічним законом і поведінкою людини, історія активної адаптації середовища існування відповідно до своїх культурних установок і потреб. Впродовж становлення та розвитку матеріального виробництва, масштаби якого різко зросли в 
результаті науково-технічної революції, природоутворювальна діяльність людини перевищила можливості саморегуляції природних систем, створила загрозу глобальної екологічної катастрофи, що підтверджується численними дослідженнями в галузі філософії екологічних криз (В. Вернадський [1], М. Голубець [3], В. Крисаченко [5], Ю. Мороз [6], В. Хесле [8] та ін.).

Різноманітність підходів до осмислення сучасних екологічних проблем, зумовили потребу в узгодженні світоглядних аспектів екологічної проблематики, розкритті філософських засад екологічної культури. 3 цього приводу В. Хесле зазначав: "Розпорошення знання призвело до занепаду філософії та нинішньої екологічної кризи, тоді як розуміння того, що лише цілісна освіта, котра дає однаково глибокі знання в природничих і гуманітарних науках, сприятиме появі людей, що зроблять вагомий внесок у справу подолання кризи, піде й на користь філософії екологічної культури" [8, 8].

Різним аспектам дослідження екологічної культури особистості присвячені численні праці вітчизняних і зарубіжних учених: гносеологічним основам (М. Дробнохот, В. Коменська, М. Гомова, Т. Чурилова та ін.), сутнісним характеристикам й особливостям розвитку (Е. Гірусов, С. Дерябо, А. Захлєбний, Г. Ільїна, І. Суравегіна, Л. Печко та ін.), структурі та місцю в системі загальнолюдської культури (О. Вербицький, А. Горлов, Б. Лихачов, А. Лук'янов, М.Моісєєв, А. Урсул, А. Фалєєв та ін.), психологічним особливостям формування (І. Белавіна, С. Глазачев, М. Вересов, Н. Дєжнікова, В. Ясвин та ін.), аксіологічним підходам до організації освітнього процесу (С. Алєксєєв, В. Бакиров, Г. Глухова, Н. Назарова, М. Нікандров, М. Тарасенко, В. Сєріков, Т. Стоєк та ін.).

На жаль, залишається недостатньо розкритим філософський аспект екологічної культури як цілісного особистісного утворення, а також $\dddot{11}$ структура, що й зумовило визначення мети статті.

Виклад основного матеріалу. На сучасному етапі для розв'язання екологічних проблем недостатньо лише правового, економічного чи технологічного регулювання процесів природокористування, оскільки головними, на нашу думку, є такі чинники, як: психологічна готовність людини впроваджувати існуючі екологічно безпечні технології; свідоме дотримання екологічних обмежень; прагнення брати особисту участь в природоохоронній діяльності тощо. Зміну системи цінностей, що дозволяють подолати відчуження людини від природи, передбачає гуманітарний напрям, а його реалізація пов'язана передовсім із системою освіти, якісним оновленням всіх її ланок з позицій екологізації.

У сучасній науковій літературі природа розглядається як цінність культури. Вона все більше набуває якісно нового статусу самоцінності, проявляється в системі пізнавальних, естетичних й етичних відносин людини до навколишнього світу. Екологічна культура $є$ тією складовою загальної культури, яка зумовлює відповідність соціальної діяльності вимогам життєпридатності природного середовища. В цьому випадку екологічна культура містить досягнення екологічного знання, екологічно продуману технологію, систему поведінки людей, спрямовану на збереження природних умов, необхідних для прогресивного розвитку суспільства.

Аналіз літературних джерел засвідчив відсутність чіткого визначення категорії “екологічна культура”. Вчені розглядають, зазвичай, різні її аспекти. I це зрозуміло, бо названа категорія порівняно нова, вона лише формується, щодо неї в науці точаться жваві дискусії, висловлюються часто протилежні думки, політизуються погляди на екологічні проблеми (варто лише згадати про оголошення президентом Д. Трампом виходу США з Паризької угоди щодо зміни клімату, укладеної в 2015 р. на 21-й Конференції учасників UNFCCC). На наш погляд, суперечності викликані тим, що два самостійних поняття “екологія" та “культура" донині не отримали чіткого загальноприйнятого визначення в науці, тому впливають на соціум і політичну поведінку окремих держав.

Відомим є той факт, що в 1866 р. німецький природодослідник і філософ Е. Геккель першим увів поняття “екологія” для позначення одного 3 розділів біології. Це поняття давно вийшло за межі біологічного знання, утворивши безліч нових наукових категорій і наукових напрямів. У сучасній науці “існує близько ста визначень екології, проте, їх узагальнення без втрати сутності виявилося дуже складним завданням”, - зазначає С. Глазачев [2, 20]. “Специфіка сучасної екології, - підкреслює М. Реймерс, - полягає в тому, що вона 3 чисто біологічної науки перетворилася у важливу галузь знань, увібравши в себе розділи географії, геології, хімії, фізики, соціології, теорії культури, економіки і навіть теології - по суті справи, всіх відомих наукових дисциплін. Розглядаючи екологію з сучасних позицій, ми виходимо за межі власне науки, вторгаючись у сферу світогляду, екологізації знання й навіть ідеології' $[7,12]$. Тому нині важко 


\section{ФІЛОСОФСЬКІ ЗАСАДИ ТА СТРУКТУРА ЕКОЛОГІЧНОӤ КУЛЬТУРИ ОСОБИСТОСТІ}

погодитися 3 трактуванням екології як наукового напряму, просто пов'язаного з природою. На наш погляд, екологічна культура існувала в усі часи, в будь-якому суспільстві й у кожної окремої людини, оскільки обидва ці суб'єкти культури знаходяться в постійній взаємодії з природним середовищем.

Стосовно поняття “культура", то нині налічується понад 400 їі визначень. Багатозначність цього поняття випливає 3 надзвичайної складності явищ, що відображаються цим терміном. Так, культура з боку різних методологічних підходів розглядається як:

1) сукупність матеріальних i духовних цінностей, створених людиною (аксіологічний підхід);

2) специфічний спосіб людської діяльності (діяльнісний підхід);

3) сукупність знакових систем, за допомогою яких соціальна інформація передається від покоління до покоління (семіотичний підхід);

4) характеристика творчої діяльності людини, iii здатності створювати щось нове (евристичний підхід) та ін.

Кожен 3 цих підходів характеризує один 3 головних аспектів культури та залежить від спрямованості й мети дослідження. Однак у всіх перерахованих підходах культура трактується як щось “неприродне”, “олюднене”.

На думку В. Крисаченко, в культурі людина представлена не як природна або надприродна субстанція, а як історично розвинена істота [5]. Розглядаючи поняття “екологічна культура", необхідно відзначити, що нині галузь екології інтенсивно досліджується культурологією в двох напрямах: як культура суспільства, і як культура особистості. Звідси, 3 погляду культури суспільства екологічна культура трактується як соціальне явище, а в межах іншого підходу екологічна культура розглядається як інтегративна особистісна якість індивіда, що характеризує його діяльність та поведінку в соціоприродному середовищі.

У дослідженні нас більше цікавить “особистісний” погляд на екологічну культуру як суб'єктивний аспект людського буття, результат саморозвитку індивіда, який виявляється в характері його діяльності та поведінці. Такий підхід притаманний для дослідників, які вивчають екологічну культуру особистості. Так, наприклад, за визначенням Л. Когана “екологічна культура це міра розкриття сутнісних сил людини, що виявляються в пї діяльності, практичному ставленні до природи" [4, 107]. С. Глазачев поглиблює це поняття, вважаючи, що екологічна культура - це "міра і спосіб реалізації та розвитку сутнісних сил людини, екологічної свідомості й мислення у процесі духовного і матеріального освоєння природи та підтримки її цілісності” [2, 24]. В. Крисаченко екологічну культуру тлумачить як цілевизначальну діяльність людини (включаючи і наслідки такої діяльності), спрямовану на організацію і трансформацію природного світу (об'єктів і процесів) відповідно до власних потреб та намірів [5, 14]. Поділяючи погляди цих учених, у дослідженні ми дотримуватимемося такого визначення: екологічна культура особистості ие соціальна й індивідуальна якість людини, яка, по-перше, відображає характер ї̈ ставлення до соиіоприродного середовища; по-друге, виявляється в иіннісних орієнтаціях, котрі мотивуюють екологічну діяльність; по-третє, реалізується в усіх видах пізнання, перетворення та збереження соиіоприродного довкілля $i$ здоров'я людини; по-четверте, зумовлена сочіальним механізмом ї̈ формування та розвитку.

Розглядаючи екологічну культуру особистості як якість людини, ми передовсім повинні виявити iii сутнісні характеристики-показники. Аналіз психолого-педагогічної літератури виявив неоднозначність трактувань сутності та структури екологічної культури. Тому, на наш погляд, дослідження цієї актуальної проблеми поки не спирається на достатньо розроблений та усталений категоріально-понятійний апарат. Зазвичай, екологічна культура особистості пов'язується з такими аспектами: відповідальним ставленням людини до природи; наявністю у неї екологічних знань і переконань; набуттям умінь та досвіду розв'язання екологічних проблем; екологічно грамотною діяльністю в природному середовищі; потребою спілкування 3 природою, турботою про ііі збереження; турботою про власне здоров'я; громадянською відповідальністю за стан соціоприродного середовища.

Грунтовний аналіз показників екологічної культури особистості (екологічне знання, екологічне мислення, екологічна освіченість, свідоме ставлення до природи та практична діяльність щодо покращення умов природокористування, багатство моральноестетичних почуттів i переживань, які породжуються спілкуванням 3 природою, екологічно відповідна поведінка та ін.) дозволив виокремити найбільш змістовні для нашого дослідження показники, а саме: екологічний світогляд особистості; когнітивний компонент екологічної культури; ціннісний компонент екологічної культури; морально-правовий 
компонент екологічної культури; чуттєвовольовий компонент екологічної культури; діяльнісний компонент. Дамо їм стислу характеристику.

Екологічний світогляд особистості - це система поглядів людини на об'єктивний світ, їі роль і місце в ньому, яка грунтується на цілісному уявленні про навколишній світ, розумінні загального взаємозв'язку всіх процесів і явищ, самоцінності всього живого і неживого, а також зумовлена цими поглядами життєва позиція людини, її цінності й ідеали, переконання, принципи пізнання та діяльності, в основі яких лежать вимоги екологічного та морального імперативів. Підгрунтя екологічного світогляду складає природоцентричний підхід до навколишнього світу. Таким чином, екологічний світогляд, будучи своєрідною духовної призмою, крізь яку сприймається і переживається особливе ставлення до природи, роль і поведінка людини в соціоприродному середовищі, є базовим компонентом, ядром екологічної культури особистості.

Когнітивний компонент екологічноӥ культури - відображає іï пізнавальну й інформативну функції, містить сукупність знань, в основі яких лежить цілісна наукова картина світу. Система екологічних знань має сприяти: 1) розумінню єдності світу та способів його осягнення; 2) розумінню системності світу, загального взаємозв'язку процесів і явищ соціоприродного середовища; 3) усвідомленню взаємозв'язку між природою і культурою людини; 4) формуванню екологічних переконань і на їх основі екологічного мислення; 5) формуванню умінь і навичок природовідповідної діяльності. Критеріями розвитку когнітивного компонента $€$ сформованість таких якостей особистості, як екологічна грамотність, ерудованість, пізнавальна активність в екологічній сфері, екологічний стиль мислення та ін.

Ціннісний компонент екологічної культури, що відображає іiі регулятивну функцію, містить цінності, ідеали та переконання, соціальні норми і правила, які регулюють поведінку та діяльність людини в соціоприродному середовищі. Він пов'язаний, $з$ одного боку, зі сприйняттям природи як універсальної цінності, від відповідального ставлення до якої залежать головні соціальні й особистісні цінності - життя та здоров'я людини, а $з$ іншого - прийняттям екологічного імперативу як системи норм і вимог, невиконання яких зумовлює екологічні катастрофи та кризи. Ціннісний компонент проявляється в таких якостях особистості, як переконаність, відповідальність, ощадливість, вимогливість до себе та оточуючих тощо.

В основі морально-правового компонента екологічної культури, що відображає ї гуманістичну функцію, лежать вимоги морального імперативу - тих норм і правил, вироблених людством тисячоліттями, які визначають поведінку та діяльність особистості в соціумі. При цьому вимоги морального імперативу, якими попередньо керувалися люди, повинні бути відкориговані з позицій сучасного екологічного імперативу: сприяти збереженню стійкості середовища проживання 3 допомогою зниження норм споживання й економії природних ресурсів. У цьому полягає сутність нового підходу до проблеми гуманізму. Цей компонент містить також і правові норми, які регламентують діяльність людини в природі. Критеріями розвиненості морально-правового компонента $\epsilon$ такі якості особистості, як гуманність, моральність, далекоглядність, громадянськість, правосвідомість, законослухняність та ін.

Чуттєво-вольовий компонент екологічної культури відображає здатність та свідоме прагнення особистості до набуття екологічних знань, освоєння цінностей, норм і правил, емоційне переживання та перетворення їх в особистісні переконання, готовність до певного типу діяльності та поведінки. Разом із ціннісним, морально-етичний компонент $є$ основою емоційної, вольової та мотиваційної сфер особистості. Чуттєво-вольової компонент проявляється в таких якостях особистості, як емоційна чуйність, здатність до співпереживання, активність, завзятість, наполегливість у досягненні мети, самодисципліна, прагнення до самореалізації й ін.

Теоретичні аспекти екологічного світогляду визначають не лише зміст, а й спосіб усвідомлення дійсності, а також принципи життя, що зумовлюють характер діяльності особистості відповідно до ії поглядів і переконань. Характер уявлень про навколишній світ, постановка певної екологічної мети, формування життєвого плану й ідеалу взаємодії з соціоприродним середовищем зумовлює екологічну діяльність, в основі якої лежать вимоги екологічного імперативу. Таким чином, можна виділити діяльнісний компонент екологічної культури.

Висновки. Отже, екологічна культура особистості формується в результаті взаємодії об'єктивних умов (система соціальних інститутів, відносин і зв'язків, які ставлять певні вимоги до особистості) та суб'єктивних чинників (соціально зумовлені спонукальні сили особистості). Цей 
процес здійснюється впродовж усього життя людини. Головними показниками екологічної культури особистості є екологічний світогляд, а також когнітивний, ціннісний, моральноправовий, чуттєво-вольовий та діяльнісний компоненти.

\section{ЛІТЕРАТУРА}

1. Вернадский В. И. Философские мысли натуралиста. Москва: Наука, 1988. 519 с.

2. Глазачев С.Н. Теоретические основы формирования экологической культуры учителя: дисс. в виде науч. доклада.: д-ра пед. наук: 13.00.08.: Москва, 1998. 68 с.

3. Голубець М. А. Від Біосфери до соціосфери. Львів: Поллі, 1997. 256 с.

4. Коган Л.Н. Экологическая культура развитого социализма. Идейно-теоретические проблемы НТП. - Свердловск, 1978. С. 100-111.

5. Крисаченко В.С. Екологічна культура: теорія і практика: навч. посібник. Київ: Заповіт, 1996. $352 \mathrm{c}$.

6. Мороз С.А. Історія біосфери Землі: навч. посібник. У 2 кн. Київ: Заповіт, 1996. Кн. 2: Геолого-палеонтологічний життєпис. 422 с.

7. Реймерс Н.Ф. Экология: теоремы, законы, правила, принципы и гипотезы. Москва: Россия молодая, 1994. - $241 \mathrm{c}$.

8. Хесле В. Философия и экология. М.: Ками, 1994. $192 \mathrm{c}$.

\section{REFERENCES}

1. Vernadskiy, V. (1988). Filosofskie myisli naturalista [Philosophical thoughts of the naturalist]. Moscow: Nauka, 519 p. [in Russian].

2. Glazachev, S. (1998). Teoreticheskie osnovyi formirovaniya ekologicheskoy kulturyi uchitelya [Theoretical bases of formation of ecological culture of the teacher]. Moscow, 68 p. [in Russian].

3. Holubets, M. (1997). Vid Biosfery do sotsiosfery [From the Biosphere to the cosmos]. Lviv: Polli, 256 p. [in Ukrainian].

4. Kogan, L. (1978). Ekologicheskaya kultura razvitogo sotsializma. Ideyno-teoreticheskie problemyi NTP [Ecological culture of developed socialism. Ideological and theoretical problems of scientific and technological progress]. Sverdlovsk, pp. 100-111. [in Russian].

5. Krysachenko, V. (1996). Ekolohichna kultura: teoriia i praktyka [Ecological culture: theory and practice]. Kyiv Zapovit, 352 p. [in Ukrainian].

6. Moroz, S. (1996). Istoriia biosfery Zemli: navch. posibnyk. U $2 \mathrm{kn}$. [History of the Earth's biosphere]. Kyiv: Zapovit. Kn. 2: Heolohopaleontolohichnyi zhyttiepys, 422 p. [in Ukrainian].

7. Reymers, N. (1994). Ekologiya: teoremyi, zakonyi, pravila, printsipyi i gipotezyi [Ecology: theorems, laws, rules, principles and hypotheses]. Moscow: Rossiya molodaya, 241 p. [in Russian].

8. Hesle, V. (1994). Filosofiya i ekologiya [Philosophy and ecology]. Moscow: Kami, 192 p. [in Russian].

Стаття надійшла до редакції 01.03.2018

\section{G5808

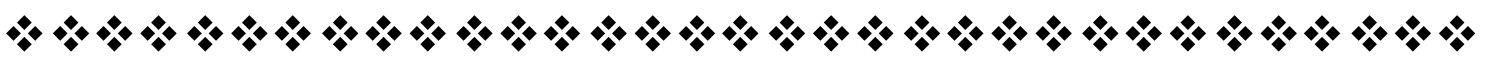

"У тому, що стосується майбутнього, я повторюю одне: за що бви не взялися, головне - будвте віддані своїи справі до кіния. Не обов'язқово досягати яқогось зоряного успіху, але бути чесним перед самим собою в обраній пробесіӥ-обов'язково".

Роберт де Hipo

американський кіноактор, режисер, продюсер

"Роби так щоб ти завжди ставився до людства і в своій особі, $і$ в особі всяқого іншого так само, якдо мети, і ніколи не ставився б до нъого тільки якдо засобу".

Іммануїл Кант німещький біілособб

“Обов'язок-ие любов до того, що сам нақазуєш собі".

$\check{\mathscr{Y} о г а н н ~ В о л ь б б а н г ~ б о н ~ Т е т е ~}$ німеиький поет, прозайк, драматург

\section{$\%+4 \%+4 \%$ c2sos}

